CLINICAL STUDY

\title{
Levels of C-peptide, body mass index and age, and their usefulness in classification of diabetes in relation to autoimmunity, in adults with newly diagnosed diabetes in Kronoberg, Sweden
}

\author{
Maria Thunander ${ }^{1,2}$, Carina Törn ${ }^{3}$, Christer Petersson ${ }^{4,5}$, Birger Ossiansson ${ }^{4}$, Jan Fornander ${ }^{4}$ and \\ Mona Landin-Olsson ${ }^{2}$ \\ ${ }^{1}$ Department of Internal Medicine, Central Hospital, S-351 85 Växjö, Kronoberg, Sweden, ${ }^{2}$ Endocrinology and Diabetology, Department of Clinical \\ Sciences, Lund University, Lund, Sweden, ${ }^{3}$ Department of Clinical Sciences, Lund University, Lund, Sweden, ${ }^{4}$ Primary Care, Kronoberg, Sweden and ${ }^{5}$ RED \\ County Council, Kronoberg, Sweden \\ (Correspondence should be addressed to M Thunander at Department of Internal Medicine, Central Hospital; Email: maria.thunander@Itkronoberg.se)
}

\begin{abstract}
Objective: C-peptide is a main outcome measure in treatment trials of diabetes. C-peptide also has a role in the classification of diabetes, which is often difficult in adults and this is also increasingly recognised in adolescents and elders.

Aim: We aimed to describe the levels of C-peptide in relation to age and body mass index (BMI) in a large population-based cohort of adults with newly diagnosed diabetes and compare the capabilities of C-peptide, age and BMI to discriminate between autoimmune and non-autoimmune diabetes. Subjects and methods: Blood samples from 1180 patients were analysed regarding islet cell antibody, glutamic acid decarboxylase antibody and fasting C-peptide (FCP). Receiver operating characteristics (ROC) curves were analysed to check the ability of age, BMI and C-peptide to discriminate between autoantibody-positive $\left(\mathrm{Ab}^{+}\right)$and -negative $\left(\mathrm{Ab}^{-}\right)$diabetes.

Results: Mean FCP was $0.73 \pm 0.5$ (range 0.13-1.80) nmol/l in the $\mathrm{Ab}^{+}$and $1.42 \pm 0.9$ (range $0.13-8.30) \mathrm{nmol} / \mathrm{l}$ in the $\mathrm{Ab}^{-}$. FCP was $0.02 \mathrm{nmol} / \mathrm{l}$ higher per year increase in age at diagnosis of diabetes. Mean BMI was $26.0 \pm 4.8$ (range $18.0-39.0$ ) $\mathrm{kg} / \mathrm{m}^{2}$ in the $\mathrm{Ab}^{+}$and $28.9 \pm 5.3$ (range 15.5-62.6) $\mathrm{kg} / \mathrm{m}^{2}$ in the $\mathrm{Ab}^{-}$. FCP increased with age also within each BMI group. The highest area under the curve (AUC) in the ROC analysis was found for C-peptide, followed by age and BMI $(0.78,0.68$ and 0.66 respectively).

Conclusions: At diagnosis of diabetes, C-peptide was superior to age and BMI in discriminating between autoimmune and non-autoimmune diabetes. C-peptide increased significantly with BMI and age, latter also within each BMI group. Most of the adults had normal or high levels of C-peptide at presentation of diabetes among the autoimmune patients.
\end{abstract}

European Journal of Endocrinology 166 1021-1029

\section{Introduction}

The importance of level of blood-cell function, measured as C-peptide, is well recognised in autoimmune diabetes both through its correlation with endogenous insulin secretion and in relation to complications $(1,2)$. Also in non-autoimmune diabetes, interest in blood-cell function has recently risen considerably $(3,4)$. Preservation of blood-cell function after diagnosis of diabetes is now a goal also in clinical trials of non-autoimmune diabetes $(4,5)$.

Classification of diabetes at presentation is often difficult in adults, especially in younger adults (6). The same difficulties are also being increasingly acknowledged in both adolescents and the elderly, where we found incidences of autoimmune diabetes as high as in the youngest age groups $(7,8)$. In addition to a clinical classification based on age, body mass index (BMI), ketoacidosis and other symptoms, there is also a need for better tools for classification, as type of diabetes has implications for choice of treatment and long-term prognosis, including development of complications (9). Different algorithms aimed to guide physicians in daily practice regarding classification have been published $(10,11)$.

Classification of diabetes with C-peptide alone was used in research settings before analysis of antibodies became prevalent (12). Classification based on treatment, a less clear definition $(13,14)$, was recommended by WHO until 1998, when new recommendations proposed classification on aetiological grounds into mainly autoimmune, or type 1 , and non-autoimmune, or type 2 , diabetes $(15,16)$. The main difference in the 
course of autoimmune and non-autoimmune diabetes is the rapid and significant decrease in endogenous insulin secretion in autoimmune diabetes compared with nonautoimmune diabetes, where insulin resistance and metabolic complications are more pronounced $(14,17)$.

\section{Objective}

The aim of this study was to describe the levels of C-peptide and BMI, and their relations to age and antibody status, in a large population-based study of adults with newly diagnosed diabetes and to explore the usefulness of C-peptide levels, BMI and age in classification of diabetes type at diagnosis of diabetes in adults.

\section{Subjects and methods}

\section{Subjects}

A prospective incidence study was performed during 3 years (1998-2001) in Kronoberg county, with 177000 inhabitants. All the 25 health care centres and the two hospitals participated. Blood samples were collected at the time of diagnosis from 98\% (1626/1666) of all newly diagnosed adults aged 18100 years (8). The majority of samples, $83 \%$ $(1355 / 1626)$, were collected in the morning after an overnight fast. We here report on the fasting C-peptide (FCP) levels of the $1180 / 1355(87 \%)$ of the patients whose data were complete, who were aged $\geq 20$ years, with mean age $65.5 \pm 14.3$, range $20-100$ years, and whose samples were collected $\leq 90$ days from diagnosis of diabetes. Of the 1295 fasting subjects with data on sampling interval, 115 (8.5\%) were excluded because the interval was $\geq 91$ days, and for 60 subjects (4.5\%), the data were incomplete. Of the 1180 samples reported here, $56.6 \%$ (668) were collected within 10 days, $23.0 \%$ (271) within 11-30 days and 20.4\% (241) within 31-90 days. The population was ethnically homogeneous with 95\% Caucasians. Patients with secondary or gestational diabetes were excluded from the initial incidence study. There were no significant differences in gender proportions, in the whole material with 50.7\% (598/1180) men, or regarding autoantibody-positive $\left(\mathrm{Ab}^{+}\right)$vs -negative $\left(\mathrm{Ab}^{-}\right), 45 \%(26 / 58)$ vs $51 \%(572 / 1120)$ men (not significant (NS)), or within the $\mathrm{Ab}^{-}$or $\mathrm{Ab}^{+}$groups $(P=0.55-85)$, or within the 10-year age groups $(P=0.16-0.70)$. The study was approved by the Ethics Committee of Lund University and performed according to the Declaration of Helsinki.

\section{Methods}

C-peptide was centrally analysed at the Department of Clinical Chemistry, Lund University Hospital, by RIA (MD315; Euro-Diagnostica AB, Malmö, Sweden).
Detection limit of the method was $0.13 \mathrm{nmol} / \mathrm{l}$, reference range $0.25-1.0 \mathrm{nmol} / \mathrm{l}$, and total variation (sum of intraand inter-assay variation) was $7 \%$. Islet cell antibody (ICA) levels were analysed with immunofluorescence with a detection limit of 9 JDF-U, sensitivity 100\% and specificity $88 \%$; glutamic acid decarboxylase antibody (GADA) levels were analysed with radioimmunoprecipitation with the lower reference limit index of 0.08 , corresponding to 21 WHO-U/ml, sensitivity of $70 \%$ and specificity of $100 \%$. Both analyses were standardised according to the Diabetes Antibody Standardization Program $(18,19)$.

The term autoimmune diabetes $\left(\mathrm{Ab}^{+}\right)$was used if subjects were positive to at least one of the antibodies to islet cells and/or glutamic acid decarboxylase. Those negative for both antibodies were designated nonautoimmune $\left(\mathrm{Ab}^{-}\right)$. Length and weight were measured by a nurse at the health care centre or hospital department and not self-reported by the patient. Calculation of BMI was possible for $98 \%$ of the fasting subjects.

The relationship between FCP and blood glucose level at the time of sampling for FCP was investigated and the potential influence on FCP of being treated with insulin or oral hypoglycemic agents (OHAs) was also explored, along with level of blood glucose. Type of OHA was not recorded, but at least $50 \%$, probably more, ought to have metformin only, according to the guidelines and praxis at the time, meaning that $<5 \%$ of all the newly diagnosed patients have been possibly treated with sulphonylurea OHA.

\section{Statistical analyses}

Descriptive statistics are reported in 10-year age groups and five BMI groups. Differences between groups were explored by ANOVA, when appropriate with post hoc Bonferroni correction, and potential interactions between levels of FCP, BMI, age, autoimmune status and sample interval (days from diagnosis to sample collection) were explored. The non-parametric KruskalWallis and Mann-Whitney $U$ tests and simple and multiple linear and logistic regression models were also applied. The sensitivity and specificity using the parameters age, BMI and C-peptide, for identifying autoimmune subjects, were explored by receiver operating characteristic (ROC) curves. All tests were two tailed, and a significance level of 0.05 was considered significant. SPSS Software (Statistical Package for the Social Sciences, Chicago, IL, USA) version 17.0 was used.

\section{Results}

\section{C-peptide}

In all the fasting subjects with newly diagnosed diabetes, mean FCP was $1.39 \pm 0.9$ (range 0.13-8.30) $\mathrm{nmol} / \mathrm{l}$. Mean FCP was significantly lower in the newly 
Table 1 Fasting C-peptide levels ( $\mathrm{nmol} / \mathrm{l})$, and BMI $\left(\mathrm{kg} / \mathrm{m}^{2}\right)$, per age group in adults with newly diagnosed diabetes. Values are mean \pm S.D.; median, min-max.

\begin{tabular}{|c|c|c|c|c|c|c|c|c|c|c|}
\hline \multirow[b]{2}{*}{$\begin{array}{l}\text { Age } \\
\text { (years) }\end{array}$} & \multicolumn{5}{|c|}{ C-peptide, fasting } & \multicolumn{5}{|c|}{ BMI } \\
\hline & $n$ & Autoimmune & $n$ & $\begin{array}{c}\text { Non- } \\
\text { autoimmune }\end{array}$ & $\begin{array}{c}P, \text { Ai vs } \\
\text { non-Ai }\end{array}$ & $n$ & Autoimmune & $n$ & $\begin{array}{c}\text { Non- } \\
\text { autoimmune }\end{array}$ & $\begin{array}{c}P, \text { Ai vs } \\
\text { non-Ai }\end{array}$ \\
\hline 20-29 & 7 & $\begin{array}{l}0.32 \pm 0.29 \\
0.23,0.13-0.96\end{array}$ & 13 & $\begin{array}{l}0.91 \pm 0.93 \\
0.66,0.19-3.5\end{array}$ & NS & 7 & $\begin{array}{l}23.9 \pm 6.2 \\
22.8,18.0-37.0\end{array}$ & 12 & $\begin{array}{l}26.1 \pm 8.2 \\
22.0,19.0-42.0\end{array}$ & NS \\
\hline 30-39 & 3 & $\begin{array}{l}0.18 \pm 0.42 \\
0.19,0.13-0.21\end{array}$ & 28 & $\begin{array}{l}1.38 \pm 0.67 \\
1.30,0.13-3.10\end{array}$ & 0.05 & 3 & $\begin{array}{l}19.0 \pm 1.0 \\
19.0,18.0-20.0\end{array}$ & 27 & $\begin{array}{l}32.0 \pm 7.0 \\
31.0,16.5-45.0\end{array}$ & 0.04 \\
\hline $40-49$ & 9 & $\begin{array}{l}0.51 \pm 0.31 \\
0.52,0.13-0.96\end{array}$ & 102 & $\begin{array}{l}1.16 \pm 0.51 \\
1.10,0.13-2.90\end{array}$ & $<0.0001$ & 9 & $\begin{array}{l}26.8 \pm 6.5 \\
24.0,20.0-39.0\end{array}$ & 101 & $\begin{array}{l}31.2 \pm 5.2 \\
31.0,19.0-46.0\end{array}$ & $<0.02$ \\
\hline $50-59$ & 14 & $\begin{array}{l}0.70 \pm 0.41 \\
0.62,0.24-1.50\end{array}$ & 214 & $\begin{array}{l}1.23 \pm 0.58 \\
1.10,0.13-5.20\end{array}$ & $<0.001$ & 14 & $\begin{array}{l}26.1 \pm 4.7 \\
26.4,19.5-38.0\end{array}$ & 212 & $\begin{array}{l}30.5 \pm 6.0 \\
29.5,16.4-62.6\end{array}$ & $<0.008$ \\
\hline $60-69$ & 9 & $\begin{array}{l}1.06 \pm 0.62 \\
1.03,0.13-1.80\end{array}$ & 261 & $\begin{array}{l}1.30 \pm 0.61 \\
1.10,0.22-4.0\end{array}$ & NS & 9 & $\begin{array}{l}27.3 \pm 3.7 \\
27.5,22.0-34.0\end{array}$ & 260 & $\begin{array}{l}29.1 \pm 4.5 \\
28.5,17.7-47.0\end{array}$ & NS \\
\hline 70-79 & 13 & $\begin{array}{l}0.94 \pm 0.53 \\
1.10,0.25-1.80\end{array}$ & 303 & $\begin{array}{l}1.55 \pm 0.99 \\
1.30,0.13-8.10\end{array}$ & $<0.03$ & 13 & $\begin{array}{l}26.8 \pm 3.0 \\
27.0,23.0-33.0\end{array}$ & 296 & $\begin{array}{l}28.6 \pm 5.0 \\
28.0,15.5-45.5\end{array}$ & NS \\
\hline $80+$ & 3 & $\begin{array}{l}1.25 \pm 0.07 \\
1.30,1.20-1.30\end{array}$ & 199 & $\begin{array}{l}1.76 \pm 1.13 \\
1.40,0.40-8.30\end{array}$ & NS & 3 & $\begin{array}{l}28.1 \pm 1.9 \\
28.2,26.0-30.0\end{array}$ & 192 & $\begin{array}{l}26.2 \pm 4.3 \\
25.0,16.0-47.7\end{array}$ & NS \\
\hline All & 58 & $\begin{array}{l}0.73 \pm 0.5 \\
0.62,0.13-1.80\end{array}$ & 1120 & $\begin{array}{l}1.42 \pm 0.9 \\
1.20,0.13-8.30\end{array}$ & $<0.0001$ & 58 & $\begin{array}{l}26.0 \pm 4.8 \\
26.0,18.0-39.0\end{array}$ & 1100 & $\begin{array}{l}28.9 \pm 5.3 \\
28.0,15.5-62.6\end{array}$ & $<0.0001$ \\
\hline
\end{tabular}

Ai, autoimmune; non-Ai, non-autoimmune.

diagnosed with autoimmune diabetes than that in the non-autoimmune group (Table 1). There was no significant mean FCP difference with regard to sex in the $\mathrm{Ab}^{+}$, but in the $\mathrm{Ab}^{-} \mathrm{FCP}$ was higher in the women, $1.48 \pm 0.84$, compared with the men, $1.37 \pm 0.87$, $P=0.03$; the range was the same.

The level of FCP increased significantly with age at diagnosis in both non-autoimmune and autoimmune adults with new diabetes (both $P<0.0001$; Table 1). For every 1-year the increase in age in the newly diagnosed, FCP was $0.02 \mathrm{nmol} / \mathrm{l}$ higher in both autoimmune and non-autoimmune diabetes (both $P<0.0001$ ); for the increase in FCP per 10-year age group, $P$ was $<0.0001$ for both diabetes types. For levels of FCP and BMI per diagnosis, age and BMI group, see Tables 1 and 2 .

Level of FCP at onset of diabetes was independently influenced by both age and BMI. Their combined influence on the level of FCP was greatest in autoimmune diabetes: $40 \%\left(R^{2}=0.398\right)$ compared with $8 \%\left(R^{2}=0.083\right)$ in non-autoimmune diabetes $(P<0.0001$ for both). FCP was $0.04 \mathrm{nmol} / \mathrm{l}$ higher per $1 \mathrm{~kg} / \mathrm{m}^{2}$ higher BMI in autoimmune and $0.03 \mathrm{nmol} / \mathrm{l}$ higher in non-autoimmune, diabetes (both $P<0.001$ ). Being $\mathrm{Ab}^{+}$meant a $0.4 \mathrm{nmol} / \mathrm{l}$ lower FCP, at the same levels of age and BMI, compared with the $\mathrm{Ab}^{-}$subjects $(P<0.001)$. Mean FCP was correlated to increasing BMI, and BMI group, and to increasing age, also within each BMI group, and this was especially apparent in non-autoimmune diabetes (Fig. 1A).

In the analysis of the three interval groups sampled ( $\leq 10$ days, within 11-30 days and within 31 to $\leq 90$ days) there was no difference in levels of FCP between any of the three groups among the $\mathrm{Ab}^{-}$ $(1.45 \pm 0.9,1.43 \pm 0.86$ and $1.31 \pm 0.64 \mathrm{nmol} / \mathrm{l}$; NS),

Table 2 Fasting C-peptide levels (nmol/l), per BMI group $\left(\mathrm{kg} / \mathrm{m}^{2}\right)$, and age (years) in adults with newly diagnosed diabetes. Values are mean \pm s.D., median, min-max.

\begin{tabular}{|c|c|c|c|c|c|c|c|c|c|}
\hline \multirow[b]{2}{*}{$\begin{array}{l}\text { BMI } \\
\text { group }\end{array}$} & & \multicolumn{5}{|c|}{ C-peptide, fasting } & \multicolumn{3}{|c|}{ Age } \\
\hline & & $n$ & Autoimmune & $n$ & $\begin{array}{c}\text { Non- } \\
\text { autoimmune }\end{array}$ & $\begin{array}{l}P \text { Ai vs } \\
\text { non-Ai }\end{array}$ & Autoimmune & $\begin{array}{c}\text { Non- } \\
\text { autoimmune }\end{array}$ & $\begin{array}{l}P \text { Ai vs } \\
\text { non-Ai }\end{array}$ \\
\hline$A$ & $<20$ & 7 & $\begin{array}{l}0.20 \pm 0.06 \\
0.22,0.13-0.31\end{array}$ & 29 & $\begin{array}{l}1.03 \pm 0.64 \\
1.0,0.19-3.60\end{array}$ & $<0.002$ & $\begin{array}{l}35.6 \pm 8.1 \\
32.0,26-50\end{array}$ & $\begin{array}{l}63.4 \pm 19.8 \\
69.0,26-95\end{array}$ & $<0.001$ \\
\hline B & 20 to $<25$ & 20 & $\begin{array}{l}0.48 \pm 0.40 \\
0.36,0.13-1.80\end{array}$ & 255 & $\begin{array}{l}1.38 \pm 1.1 \\
1.0,0.13-8.30\end{array}$ & $<0.0001$ & $\begin{array}{l}51.7 \pm 17.4 \\
52.0,22-77\end{array}$ & $\begin{array}{l}71.7 \pm 13.9 \\
75.0,23-94\end{array}$ & $<0.0001$ \\
\hline C & 25 to $<30$ & 21 & $\begin{array}{l}1.09 \pm 0.38 \\
1.20,0.52-1.80\end{array}$ & 440 & $\begin{array}{l}1.36 \pm 0.8 \\
1.20,0.13-7.80\end{array}$ & NS & $\begin{array}{l}65.1 \pm 11.7 \\
65.0,40-82\end{array}$ & $\begin{array}{l}66.7 \pm 12.3 \\
67.0,31-94\end{array}$ & NS \\
\hline D & 30 to $<35$ & 6 & $\begin{array}{l}0.91 \pm 0.67 \\
1.15,0.25-1.80\end{array}$ & 250 & $\begin{array}{l}1.47 \pm 0.7 \\
1.30,0.44-5.30\end{array}$ & $<0.04$ & $\begin{array}{l}60.3 \pm 13.8 \\
65.5,43-73\end{array}$ & $\begin{array}{l}62.7 \pm 13.3 \\
63.0,21-96\end{array}$ & NS \\
\hline E & $\geq 35$ & 4 & $\begin{array}{l}0.61 \pm 0.32 \\
0.51,0.35-0.96\end{array}$ & 126 & $\begin{array}{l}1.62 \pm 0.8 \\
1.50,0.13-6.40\end{array}$ & $<0.02$ & $\begin{array}{l}42.3 \pm 14.5 \\
42.0,28-57\end{array}$ & $\begin{array}{l}59.1 \pm 13.9 \\
58.0,23-93\end{array}$ & 0.04 \\
\hline & All & 58 & $\begin{array}{l}0.76 \pm 0.53 \\
0.62,0.13-1.9\end{array}$ & 1100 & $\begin{array}{l}1.39 \pm 0.84 \\
1.20,0.13-8.3\end{array}$ & $<0.0001$ & $\begin{array}{l}55.1 \pm 16.9 \\
55.0,22-82\end{array}$ & $\begin{array}{l}66.1 \pm 14.0 \\
67.0,21-100\end{array}$ & $<0.0001$ \\
\hline
\end{tabular}

Ai, autoimmune; non-Ai, non-autoimmune. 

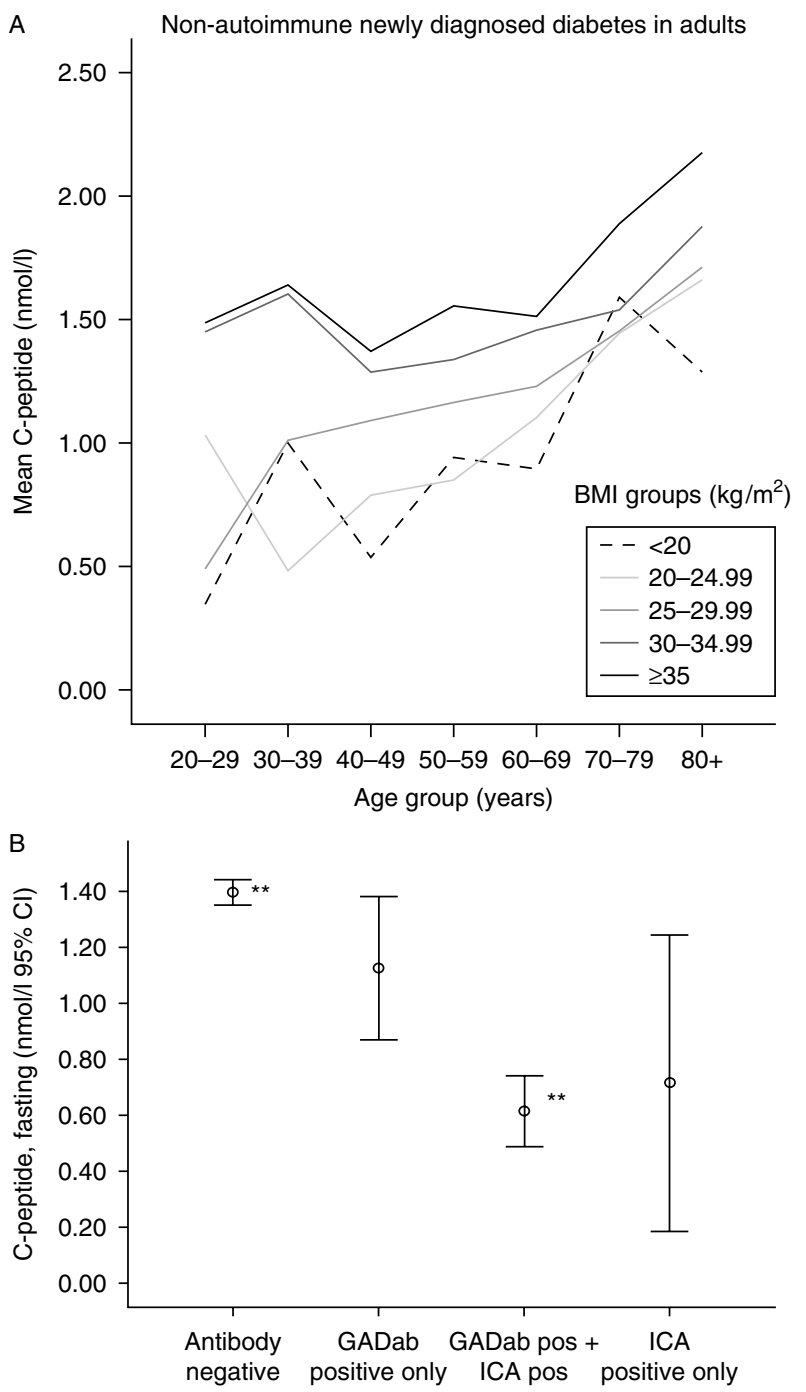

Figure $1(A)$ Mean fasting C-peptide (nmol/l), per age and BMI group in non-autoimmune diabetes. (B) Mean fasting C-peptide, including $95 \%$ confidence intervals, per antibody positivity; all in adults with newly diagnosed diabetes. ${ }^{\star \star} P<0.001$.

while in the $\mathrm{Ab}^{+}, \mathrm{FCP}$ was significantly lower in the $\leq 10$ days sampling, interval $(0.57 \pm 0.45)$ compared with the 31- to 90-day interval $(1.19 \pm 0.51 \mathrm{nmol} / \mathrm{l})$, $P=0.02$. FCP in the 11- to 30-day group $(0.79 \pm$ $0.47 \mathrm{nmol} / \mathrm{l}$ ) did not significantly differ from any of the other two interval groups $(P=0.2-0.8)$. Per increased interval of 1 day (from 0 to 90 days) from diabetes diagnosis to sampling, FCP was $0.003 \mathrm{nmol} / \mathrm{l}$ lower at the time of sampling in the $\mathrm{Ab}^{-}, P=0.02$; in the $\mathrm{Ab}^{+}$, it was 0.0009 higher, $P=0.004$. The corresponding figures for BMI were $+0.02 \mathrm{~kg} / \mathrm{m}^{2}$ among $\mathrm{Ab}^{-}$, $P=0.002$, and among $\mathrm{Ab}^{+},+0.08 \mathrm{~kg} / \mathrm{m}^{2}, P=0.02$. In the interaction analysis with sample interval only autoimmunity significantly influenced level of FCP, and not age nor interval. Sampling interval significantly influenced level of FCP in the autoimmune subgroup but had no influence on FCP in the non-autoimmune group, confirmed by logistic regression where $R^{2}$ for interval was only $0.04(4 \%)$ in the $\mathrm{Ab}^{-}, P=0.02$, and slightly higher, $0.123(12 \%), P=0.01$, in the $\mathrm{Ab}^{+}$.

Of the 1180 patients, $58(4.9 \%)$ were autoimmune. Eighty three percent $(926 / 1120)$ of the $\mathrm{Ab}^{-}, 41.4 \%$ $(24 / 58)$ of the $\mathrm{Ab}^{+}$and $80.5 \%$ of all $(950 / 1180)$ were treated with diet only, no insulin or OHAs, at the time of sampling. In total, $11.7 \%(138 / 1180)$ were treated with OHAs: for $\mathrm{Ab}^{-}$patients, this was $11.8 \%$ $(132 / 1120)$ and for $\mathrm{Ab}^{+} 33 \%(19 / 58)$. Nine $\mathrm{Ab}^{-}$and two $\mathrm{Ab}^{+}$patients $(11 / 1180,0.9 \%)$ were treated with both OHA and insulin. Insulin treatment was already initiated in $7.6 \%(90 / 1180)$ of the patients, $6.3 \%$ (71/1120) $\mathrm{Ab}^{-}$and 33\% (19/58) $\mathrm{Ab}^{+}$. In the $\mathrm{Ab}^{-}$, there were no significant differences in the level of mean FCP between the different treatment groups. FCP levels were as follows: for diet only, 1.43 \pm 0.8 ; for OHA treated, $1.36 \pm 0.96$; for insulin treated, $1.35 \pm 1.1$; and for $\mathrm{OHA}+$ insulin treated, $1.07 \pm 0.57 \mathrm{nmol} / \mathrm{l}$; in the $\mathrm{Ab}^{+}, 1.03 \pm 0.0 .47,0.80 \pm 0.49,0.31 \pm 0.22$ and $0.33 \pm 0.28 \mathrm{nmol} / \mathrm{l}$ respectively. In the $\mathrm{Ab}^{+}$, the insulin treated had a significantly lower mean level of C-peptide at diagnosis of diabetes than both the diet-only and the OHA-treated groups $(P<0.0001$ and 0.01 respectively). Complete data for multiple regression analyses were available for $88.3 \%(1042 / 1180)$. Mean blood glucose at sampling (in the 1042 and 1180) was $8.2 \pm 2.9 \mathrm{mmol} / \mathrm{l}$ (range 1.4-24.2) $\mathrm{mmol} / \mathrm{l}$. Only one subject had blood glucose in the hypoglycemic range, $<3 \mathrm{mmol} / \mathrm{l}$, while $79 \%(820 / 1042)$ had blood glucose $3.0-10.0 \mathrm{mmol} / \mathrm{l}, 21 \%$ (219/1042) 10.1-20.0 mmol/l and two individuals $\geq 20.0 \mathrm{mmol} / \mathrm{l}$.

The relationship between FCP and blood glucose level at the time of sampling for FCP was explored in a multiple regression model including age and autoimmune status. Level of blood glucose had no influence at all on level of FCP, $P=0.75$. Both age and autoimmunity, however, influenced level of C-peptide significantly $(P<0.0001)$. In another multiple regression model, the potential influence of blood glucose on FCP in relation to treatment with insulin or OHAs at the time of the sampling was calculated. There was still no correlation between FCP and blood glucose $(P=0.40)$, and there were no correlations between FCP and treatment with OHAs $(P=0.14)$, but there was a significant relation between being treated with insulin early and level of FCP $(P=0.001)$.

\section{BMI and age}

Mean BMI for all was $28.8 \pm 5.4$ (range 15.5-62.6) $\mathrm{kg} / \mathrm{m}^{2}$. Mean BMI for the $\mathrm{Ab}^{+}$was significantly lower than that for the $\mathrm{Ab}^{-}(P<0.0001$; Table 1). The women had higher mean BMI level than the men, both the autoimmune, $27.4 \pm 5.5$ vs $24.5 \pm 3.4 \mathrm{~kg} / \mathrm{m}^{2}$ $(P<0.03)$, and the non-autoimmune, $29.4 \pm 5.6$ vs 
A

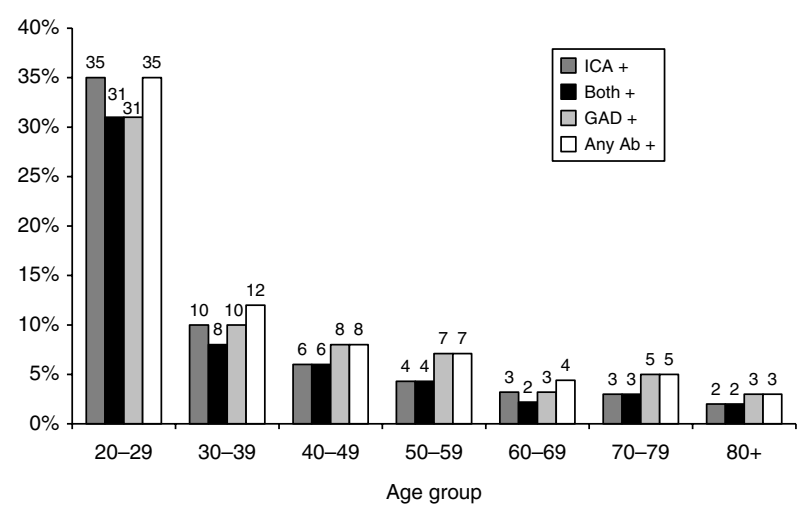

B

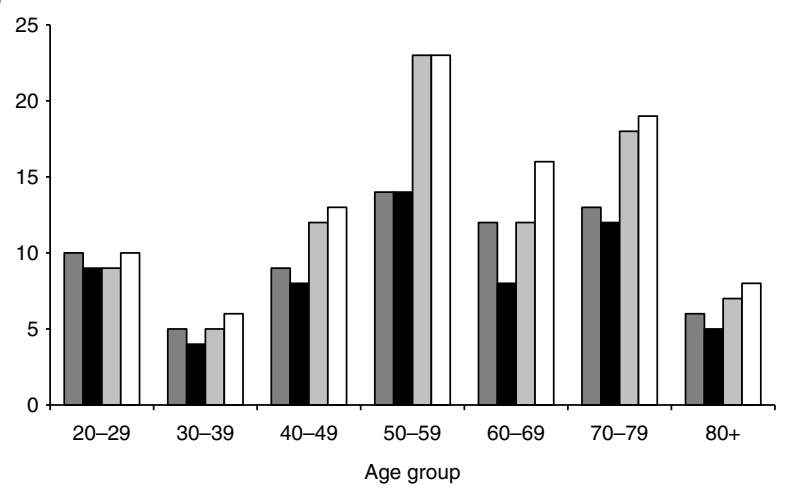

Figure 2 Prevalence of antibodies per age group in percent $(A)$ and absolute numbers (B) in adults with newly diagnosed diabetes.

$28.5 \pm 5.0 \mathrm{~kg} / \mathrm{m}^{2}(P<0.01)$. For BMI in different age groups, see Table 1 and Fig. 1A. In the younger adult age groups, especially ages $30-50$ years, among those who were newly diagnosed with non-autoimmune diabetes had the highest mean levels of BMI, which then decreased with increasing age at onset $(P<0.0001)$. The women were older than the men at diagnosis of $\mathrm{Ab}^{-}$diabetes, $66.4 \pm 14.5$, min 22, max 100 vs $64.1 \pm 14.3, \min 21, \max 94$ years $(P<0.003)$.
Mean $\mathrm{BMI}$ in the $\mathrm{Ab}^{-}$did not differ significantly from neither the only $\mathrm{GADA}^{+}$nor the only $\mathrm{ICA}^{+}$, nor from those positive to both antibodies. There were no significant differences in BMI between the different $\mathrm{Ab}^{+}$groups.

\section{Autoimmunity}

Mean FCP levels in those negative to both antibodies were significantly higher than those positive to both antibodies $(P<0.001)$, but with correction for multiple comparisons were not significantly different from those positive to only one antibody, GADA or ICA, and there were no significant differences in the levels of C-peptide between any of the $\mathrm{Ab}^{+}$groups (Fig. 1B). The mean FCP in only $\mathrm{GADA}^{+}$subjects, $1.06 \pm 0.53$, range $0.17-1.80$, was lower than that in the $\mathrm{Ab}^{-}$, $1.42 \pm 0.85$, range $0.13-8.30$, but the difference did not reach significance (Fig. 1B). The majority of the $\mathrm{Ab}^{+}$subjects were both GADA ${ }^{+}$and $\mathrm{ICA}^{+}$(Fig. $2 \mathrm{~A}$ and B). The $\mathrm{Ab}^{+}$proportion of newly diagnosed subjects was highest in the adult age groups below 60 years, peaking at age 20-29 years (Fig. 2A). The proportion of $\mathrm{Ab}^{+}$subjects among the newly diagnosed was $3-5 \%$ in ages 60-100 years. The proportion of newly diagnosed that was $\mathrm{Ab}^{+}$decreased with age, but the absolute numbers of $\mathrm{Ab}^{+}$subjects were higher in the 50- to 80 -year olds than in the younger age groups (Fig. 2B). Among subjects with BMI $\leq 20 \mathrm{~kg} / \mathrm{m}^{2}, 15-20 \%$ were $\mathrm{Ab}^{+}$, as were $5-7 \%$ among those with BMI 20$25 \mathrm{~kg} / \mathrm{m}^{2}$ and $<5 \%$ among BMI $\geq 25 \mathrm{~kg} / \mathrm{m}^{2}$.

\section{ROC analysis}

ROC curves for the fasting subjects are displayed in Fig. 3. AUC for FCP was superior to those for age and $\mathrm{BMI}$ for differentiating between $\mathrm{Ab}^{+}$and $\mathrm{Ab}^{-}$subjects. AUC was $0.78 \pm 0.04(0.71-0.85)$ for C-peptide, $0.68 \pm 0.04(0.61-0.76)$ for age and $0.66 \pm 0.04$ $(0.59-0.73)$ for BMI $(P<0.0001$ for all). For sensitivity and specificity, see Fig. 3.

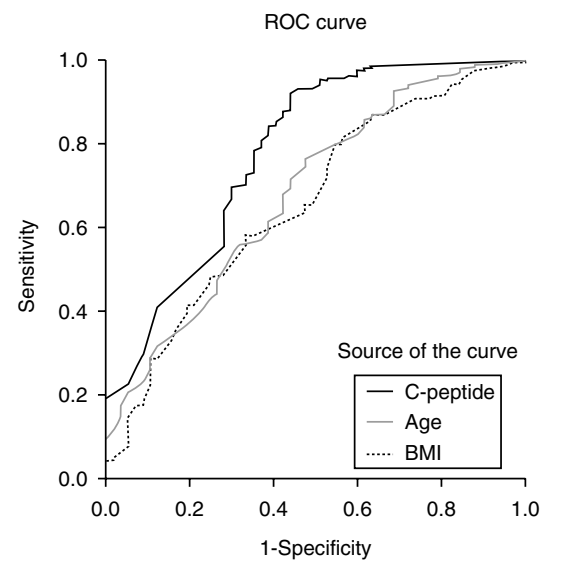

\begin{tabular}{|c|c|c|}
\hline Fasting C-peptide (nmol/l) & Sensitivity (\%) & Specificity (\%) \\
\hline 0.50 & 96 & 40 \\
\hline 0.60 & 94 & 51 \\
\hline 0.70 & 89 & 66 \\
\hline 0.80 & 83 & 61 \\
\hline 0.90 & 76 & 65 \\
\hline 1.00 & 66 & 71 \\
\hline \multicolumn{3}{|l|}{ Age (years) } \\
\hline 40 & 97 & 18 \\
\hline 50 & 87 & 34 \\
\hline 55 & 77 & 53 \\
\hline \multicolumn{3}{|l|}{ BMI $\left(\mathrm{kg} / \mathrm{m}^{2}\right)$} \\
\hline 23.0 & 87 & 27 \\
\hline 24.0 & 81 & 44 \\
\hline 25.0 & 74 & 47 \\
\hline
\end{tabular}

Figure $3 \mathrm{ROC}$ analysis of C-peptide, $\mathrm{BMI}$ and age to identify subjects that are autoimmune. 


\section{Discussion}

\section{C-peptide}

C-peptide level at diagnosis of both autoimmune and non-autoimmune diabetes increased with age at onset, which has been described, mostly in younger patients (20). Similar to our findings, FCP increased by $2 \%$ per year from age at onset in newly diagnosed Italian type 1 patients aged 0-49 years (21). Of our newly diagnosed adults above the age of 40 years with autoimmune diabetes, 95\% had detectable C-peptide compared with $60 \%$ in the 15- to 34-year olds in the Diabetes Incidence Study in Sweden (22). The same trend was found in non-diabetic subjects and was experimentally demonstrated to be due to increasing insulin resistance with age independent of BMI (23). Our elderly patients had higher FCP than those healthy elders, probably due to a dominating insulin resistance at onset of diabetes (23, 24, 25).

C-peptide at diagnosis was increased with increasing BMI level and also with age within each BMI group, emphasising the independent influence of age on C-peptide. The women had higher levels of BMI and were older at presentation of $\mathrm{Ab}^{-}$diabetes than the men, and consequently also had higher C-peptide levels compared with the men. Men are usually more prone to abdominal and visceral rather than subcutaneous fat distribution, and visceral fat is not as well reflected by BMI $(26,27)$.

The Botnia study found significantly lower levels of FCP than we did, 0.46 vs $0.62 \mathrm{nmol} / \mathrm{l}$, in $\mathrm{GADA}^{+}$vs $\mathrm{GADA}^{-}$patients (17); the levels showed the same relation but both lower than ours, probably due to the longer duration of diabetes that was $6 \pm 10$ years, while in the Kronoberg study, all patients were recently diagnosed. Our levels of C-peptide may differ from those found in other studies due to differences in age, as we also included the eldest age groups, in which diabetes is most prevalent $(8,28,29,30)$. In contrast to the prevailing notion that level of blood glucose influences level of peptide, we found no evidence of such influence in this cohort. A minority of the patients in this study were treated with OHAs or insulin at the time of the study, and treatment was withheld on the morning of the fasting sampling, therefore it is not likely that these factors had any major influence on the results. The majority of the patients $(88 \%)$ were treated with diet only at the time of sampling for FCP, and it was only in the already insulin-C-treated $\mathrm{Ab}^{+}$patients that there was a significant correlation between level of blood glucose at sampling and level of FCP $(P=0.003)$.

\section{Body mass index}

Our findings that the most obese subjects were affected by non-autoimmune diabetes earlier in life than the less obese were in accordance with a registry study from
Oregon (31). The levels of BMI that we found were lower than those in the Oregon study, but higher than those in the Botnia study, probably due to differences in ethnicities and duration after onset of diabetes (17, 31 ). The trend of negative correlation between BMI and age in $\mathrm{Ab}^{-}$diabetes was similar in the Botnia study. We also analysed this relation in patients with $\mathrm{Ab}^{+}$diabetes and found an opposite trend. This, in combination with that the majority of the adults with newly diagnosed diabetes, independently of presence of autoantibodies, had BMI in the overweight or obese ranges, accentuates the limitation in using BMI for distinction between diabetes types. The ROC analysis ranked BMI after both C-peptide and age regarding ability to detect autoimmune diabetes. In accordance with this, one study found that a combination of antibodies and C-peptide was found to have the highest predictive value for ketose-prone diabetes (32). The explanatory rate for C-peptide level of age and BMI was greater in autoimmune than in non-autoimmune diabetes, 39 vs $8 \%$. This indicates that the major explanations are due to other factors and that the relations between insulin resistance and blood-cell function are more complex, which has also been demonstrated experimentally (33).

\section{Autoimmunity}

Considering that we also included the oldest age groups, with most prevalent diabetes, the prevalence of patients positive to at least one pancreatic autoantibody was in accordance with previous studies, such as UKPDS and the Botnia study $(8,17,34)$. Some early studies analysed only one antibody $(17,28,29,34)$. The differences in frequency of $\mathrm{Ab}^{+}$between studies can be explained by the number and types of antibodies analysed, duration of diabetes as well as ages in the populations studied.

The proportion of $\mathrm{Ab}^{+}$subjects among our newly diagnosed patients decreased with age and was $3-5 \%$ in ages 60-100 years. However, the absolute numbers of subjects positive to at least one antibody was higher in the 50- to 80-year olds than in the younger adult age groups due to the larger number of individuals affected by diabetes in the older age groups (8).

\section{Classification}

Age and BMI are among the most frequently used tools for clinical classification but seldom tested in an evidence-based manner. In our large population-based cohort of newly diagnosed patients, we found that, while still not ideal, C-peptide was a better discriminator than both age and BMI for identifying those positive to at least one of GADA and/or ICA, and C-peptide AUC reached the same level in ROC analysis as several classification schemes for ketosis-prone diabetes (32).

The reasons for assigning individuals with diabetes to different subgroups are both to facilitate research 
regarding all aspects from pathophysiology to new treatments and prevention and for clinical use when recommending treatment to patients $(35,36)$. Concomitantly, there are also limitations to the use of classifications (37).

The emergence of different treatments for different types of diabetes, reactualised by the latest new group of anti-diabetic drugs, the incretin-based therapies and by treatments aiming for prevention, relief and cure of autoimmune diabetes, all put new focus on blood-cell function $(4,5,38)$, which is still best estimated by C-peptide (39). C-peptide is available in standard commercial assays, is not very costly and ought to be readily available in many settings.

Previously, the difficulties of classification and thereby of recommending the optimal treatment and follow-up for patients were identified to be problems of young adults, but now it appears as a problem of all ages, not least in the elderly, where diabetes is most frequent $(7,8)$.

Autoantibodies predict insulin dependency within 3-6 years in the majority of adult patients diagnosed with diabetes $(34,40)$. In the latest recommendation by WHO, LADA is considered a variant of autoimmune, or type 1 diabetes $(15,16)$, and many share that view $(36,41,42)$, but it is also debated (37). A useful classification of diabetes type can save time, effort and concern, and thereby costs, for health care providers and patients; it may increase patient security and possibility of empowerment and minimise risks (30, 32, $41,43)$. As the number of adults with autoimmune diabetes are larger than those diagnosed with autoimmune diabetes during childhood, many patients are affected (8, 44). They have a decreasing blood-cell function and are at risk of ketoacidosis. Delay of insulin treatment and prolonged time with deteriorated blood glucose involves risk of earlier debut of complications $(9,32,41,45,46)$.

\section{Conclusions}

C-peptide level at diagnosis of diabetes was superior to both age and BMI in discriminating between autoimmune and non-autoimmune diabetes; it increased with increasing BMI, and age, and later even within each BMI group. Analysis of C-peptide is less expensive than antibody analyses and better than both BMI and age at indicating autoimmune diabetes, information that affects both choice of treatment and follow-up; therefore, C-peptide can be a good complement in clinical practice in many settings.

\section{Declaration of interest}

The authors declare that there is no conflict of interest that could be perceived as prejudicing the impartiality of the research reported.

\section{Funding}

The work was financed by the Health Care Regions of Skane and Kronoberg, Southern Sweden; Lund University funding of Clinical research (ALF) and the Swedish Council of Medical Research, grant no K97-19X12242.

\section{Acknowledgements}

The authors wish to thank the physicians and diabetes nurses of Kronoberg; the patients; PhDs Anna Lindgren, Center of Mathematical Sciences, Lund Institute of Technology, and Per Nyberg, Medical Faculty, both Lund University, for statistical advice; Ass. Prof. Anders Isaksson, Department of Clinical Chemistry, Lund University Hospital, for the analyses of C-peptide; and Lena Widén, Kronoberg County Council R\&D for expert secretarial assistance.

\section{References}

1 Faber OK \& Binder C. B-cell function and blood glucose control in insulin dependent diabetics within the first month of insulin treatment. Diabetologia 197713 263-268. (doi:10.1007/BF 01219710)

2 Steffes MW, Sibley S, Jackson M \& Thomas W. Beta-cell function and the development of diabetes-related complications in the diabetes control and complications trial. Diabetes Care 200326 832-836. (doi:10.2337/diacare.26.3.832)

3 Palmer AJ, Roze S, Valentine WJ, Minshall ME, Lammert M, Oglesby A, Hayes C \& Spinas GA. What impact would pancreatic beta-cell preservation have on life expectancy, quality-adjusted life expectancy and costs of complications in patients with type 2 diabetes? A projection using the CORE Diabetes Model. Current Medical Research and Opinion 200420 (Suppl 1) S59-S66. (doi:10.1185/030079904X2024)

4 Marchetti P, Lupi R, Del Guerra S, Bugliani M, D’Aleo V, Occhipinti M, Boggi U, Marselli L \& Masini M. Goals of treatment for type 2 diabetes: beta-cell preservation for glycemic control. Diabetes Care 200932 (Suppl 2) S178-S183. (doi:10.2337/dc09S306)

5 Zinman B, Gerich J, Buse JB, Lewin A, Schwartz S, Raskin P, Hale PM, Zdravkovic M \& Blonde L. Efficacy and safety of the human glucagon-like peptide-1 analog liraglutide in combination with metformin and thiazolidinedione in patients with type 2 diabetes (LEAD-4 Met+TZD). Diabetes Care 200932 1224-1230. (doi:10.2337/dc08-2124)

6 Arnqvist HJ, Littorin B, Nystrom L, Schersten B, Ostman J, Blohme G, Lithner F \& Wibell L. Difficulties in classifying diabetes at presentation in the young adult. Diabetic Medicine 199310 606-613. (doi:10.1111/j.1464-5491.1993.tb00132.x)

7 Gilliam LK, Brooks-Worrell BM, Palmer JP, Greenbaum CJ \& Pihoker C. Autoimmunity and clinical course in children with type 1, type 2, and type 1.5 diabetes. Journal of Autoimmunity 200525 244-250. (doi:10.1016/j.jaut.2005.09.013)

8 Thunander M, Petersson C, Jonzon K, Fornander J, Ossiansson B, Torn C, Edvardsson S \& Landin-Olsson M. Incidence of type 1 and type 2 diabetes in adults and children in Kronoberg, Sweden. Diabetes Research and Clinical Practice 200882 247-255. (doi:10.1016/j.diabres.2008.07.022)

9 Brophy S, Brunt $H$, Davies H, Mannan S \& Williams R. Interventions for latent autoimmune diabetes (LADA) in adults. Cochrane Database of Systematic Reviews 200718 CD006165.

10 Fourlanos S, Perry C, Stein MS, Stankovich J, Harrison LC \& Colman PG. A clinical screening tool identifies autoimmune diabetes in adults. Diabetes Care 200629 970-975. (doi:10.2337/ dc05-2101)

11 Lutgens MW, Meijer M, Peeters B, Poulsen ML, Rutten MJ, Bots ML, van der Heijden GJ \& Soedamah-Muthu SS. Easily obtainable 
clinical features increase the diagnostic accuracy for latent autoimmune diabetes in adults: an evidence-based report. Primary Care Diabetes 20082 207-211. (doi:10.1016/j.pcd.2008.08.003)

12 Gjessing HJ, Matzen LE, Faber OK \& Froland A. Fasting plasma C-peptide, glucagon stimulated plasma C-peptide, and urinary C-peptide in relation to clinical type of diabetes. Diabetologia 1989 32 305-311. (doi:10.1007/BF00265547)

13 Report of a WHO Study Group. World Health Organisation, Tech Rep Ser no 727, 1985.

14 Bennett P \& Knowler WC. Definition, diagnosis and classification of diabetes mellitus and glucose homeostasis. In Joslins Diabetes Mellitus, pp 331-339. Ed EA Kahn. Boston: Lipincott, Williams \& Wilkins, 2005.

15 Alberti KG \& Zimmet PZ. Definition, diagnosis and classification of diabetes mellitus and its complications. Part 1: diagnosis and classification of diabetes mellitus provisional report of a WHO consultation. Diabetic Medicine 199815 539-553. (doi:10.1002/ (SICI) 1096-9136(199807)15:7 < 539::AID-DIA668> 3.0.CO;2-S)

16 Diagnosis and classification of diabetes mellitus. Diabetes Care 201033 Suppl 1 S62-S69.

17 Tuomi T, Carlsson A, Li H, Isomaa B, Miettinen A, Nilsson A, Nissen M, Ehrnstrom BO, Forsen B, Snickars B, Lahti K, Forsblom C, Saloranta C, Taskinen MR \& Groop LC. Clinical and genetic characteristics of type 2 diabetes with and without GAD antibodies. Diabetes 199948 150-157. (doi:10.2337/diabetes. 48.1.150)

18 Verge CF, Stenger D, Bonifacio E, Colman PG, Pilcher C, Bingley PJ \& Eisenbarth GS. Combined use of autoantibodies (IA-2 autoantibody, GAD autoantibody, insulin autoantibody, cytoplasmic islet cell antibodies) in type 1 diabetes: Combinatorial Islet Autoantibody Workshop. Diabetes 199847 1857-1866. (doi:10.2337/ diabetes.47.12.1857)

19 Bingley PJ, Bonifacio E \& Mueller PW. Diabetes Antibody Standardization Program: first assay proficiency evaluation. Diabetes 200352 1128-1136. (doi:10.2337/diabetes.52.5.1128)

20 Picardi A, Visalli N, Lauria A, Suraci C, Buzzetti R, Merola MK, Manfrini S, Guglielmi C, Gentilucci UV, Pitocco D, Crino A, Bizzarri C, Cappa M \& Pozzilli P. Metabolic factors affecting residual beta cell function assessed by $\mathrm{C}$-peptide secretion in patients with newly diagnosed type 1 diabetes. Hormone and Metabolic Research 200638 668-672. (doi:10.1055/s-2006-954586)

21 Petrone A, Galgani A, Spoletini M, Alemanno I, Di Cola S, Bassotti G, Picardi A, Manfrini S, Osborn J, Pozzilli P \& Buzzetti R. Residual insulin secretion at diagnosis of type 1 diabetes is independently associated with both, age of onset and HLA genotype. Diabetes/Metabolism Research and Reviews 200521 271-275. (doi:10.1002/dmrr.549)

22 Jensen R, Gilliam L, Torn C, Landin-Olsson M, Palmer J, Akesson K, Kockum I, Lernmark B, Karlsson AF, Lynch KF, Breslow N, Lernmark A \& Sundkvist G. Islet cell autoantibody levels after the diagnosis of young adult diabetic patients. Diabetic Medicine 2007 24 1221-1228. (doi:10.1111/j.1464-5491.2007.02235.x)

23 Basu R, Dalla Man C, Campioni M, Basu A, Klee G, Toffolo G, Cobelli C \& Rizza RA. Effects of age and sex on postprandial glucose metabolism: differences in glucose turnover, insulin secretion, insulin action, and hepatic insulin extraction. Diabetes $2006 \mathbf{5 5}$ 2001-2014. (doi:10.2337/db05-1692)

24 Greenbaum CJ, Anderson AM, Dolan LM, Mayer-Davis EJ, Dabelea D, Imperatore G, Marcovina S \& Pihoker C. Preservation of beta-cell function in autoantibody-positive youth with diabetes. Diabetes Care 200932 1839-1844. (doi:10.2337/dc08-2326)

25 Tsai EB, Sherry NA, Palmer JP \& Herold KC. The rise and fall of insulin secretion in type 1 diabetes mellitus. Diabetologia 200649 261-270. (doi:10.1007/s00125-005-0100-8)

26 Kuk JL, Saunders TJ, Davidson LE \& Ross R. Age-related changes in total and regional fat distribution. Ageing Research Reviews 20098 339-348. (doi:10.1016/j.arr.2009.06.001)

27 Geer EB \& Shen W. Gender differences in insulin resistance, body composition, and energy balance. Gender Medicine 20096 (Suppl 1) 60-75. (doi:10.1016/j.genm.2009.02.002)
28 Clauson P, Linnarsson R, Gottsater A, Sundkvist G \& Grill V. Relationships between diabetes duration, metabolic control and beta-cell function in a representative population of type 2 diabetic patients in Sweden. Diabetic Medicine 199411 794-801. (doi:10.1111/j.1464-5491.1994.tb00355.x)

29 Gottsater A, Landin-Olsson M, Fernlund P, Lernmark A \& Sundkvist G. Beta-cell function in relation to islet cell antibodies during the first $3 \mathrm{yr}$ after clinical diagnosis of diabetes in type II diabetic patients. Diabetes Care 199316 902-910. (doi:10.2337/ diacare.16.6.902)

30 Tfayli H, Bacha F, Gungor N \& Arslanian S. Islet cell antibodypositive versus -negative phenotypic type 2 diabetes in youth: does the oral glucose tolerance test distinguish between the two? Diabetes Care 201033 632-638. (doi:10.2337/dc09-0305)

31 Hillier TA \& Pedula KL. Characteristics of an adult population with newly diagnosed type 2 diabetes: the relation of obesity and age of onset. Diabetes Care 200124 1522-1527. (doi:10.2337/diacare. 24.9.1522)

32 Balasubramanyam A, Garza G, Rodriguez L, Hampe CS, Lakshmi G, Lernmark A \& Maldonado MR. Accuracy and predictive value of ketosis-prone diabetes. Diabetes Care 200629 2575-2579. (doi:10.2337/dc06-0749)

33 Ferrannini E, Gastaldelli A, Miyazaki Y, Matsuda M, Mari A \& DeFronzo RA. Beta-cell function in subjects spanning the range from normal glucose tolerance to overt diabetes: a new analysis. Journal of Clinical Endocrinology and Metabolism 200590 493-500. (doi:10.1210/jc.2004-1133)

34 Turner R, Stratton I \& Horton V. UKPDS: autoantibodies to isletcell cytoplasm and glutamic acid decarboxylase for prediction of insulin requirement in type 2 diabetes. Lancet $1997 \mathbf{3 5 0}$ 1288-1293. (doi:10.1016/S0140-6736(97)03062-6)

35 Bronstein J \& Lawrence RD. Two types of diabetes mellitus, with and without available plasma insulin. BMJ $1951 \quad 1732$. (doi:10.1136/bmj.1.4709.732)

36 Rolandsson $\mathrm{O} \&$ Palmer JP. Latent autoimmune diabetes in adults (LADA) is dead: long live autoimmune diabetes. Diabetologia 2010 53 1250-1253. (doi:10.1007/s00125-010-1713-0)

37 Gale EAM. Declassifying diabetes. Diabetologia 2006 49 1989-1995. (doi:10.1007/s00125-006-0348-7)

38 Keymeulen B, Vandemeulebroucke E, Ziegler AG, Mathieu C, Kaufman L, Hale G, Gorus F, Goldman M, Walter M, Candon S, Schandene L, Crenier L, De Block C, Seigneurin JM, De Pauw P, Pierard D, Weets I, Rebello P, Bird P, Berrie E, Frewin M, Waldmann H, Bach JF, Pipeleers D \& Chatenoud L. Insulin needs after CD3-antibody therapy in new-onset type 1 diabetes. New England Journal of Medicine 2005352 2598-2608. (doi:10. 1056/NEJMoa043980)

39 Palmer JP, Fleming GA, Greenbaum CJ, Herold KC, Jansa LD, Kolb H, Lachin JM, Polonsky KS, Pozzilli P, Skyler JS \& Steffes MW. C-peptide is the appropriate outcome measure for type 1 diabetes clinical trials to preserve beta-cell function: report of an ADA workshop, 21-22 October 2001. Diabetes 200453 250-264. (doi:10.2337/diabetes.53.1.250)

40 Landin-Olsson M, Nilsson KO, Lernmark A \& Sundkvist G. Islet cell antibodies and fasting C-peptide predict insulin requirement at diagnosis of diabetes mellitus. Diabetologia 199033 561-568. (doi:10.1007/BF00404145)

41 Fourlanos S, Dotta F, Greenbaum CJ, Palmer JP, Rolandsson O, Colman PG \& Harrison LC. Latent autoimmune diabetes in adults (LADA) should be less latent. Diabetologia 200548 2206-2212. (doi:10.1007/s00125-005-1960-7)

42 Leslie RD, Williams R \& Pozzilli P. Clinical review: type 1 diabetes and latent autoimmune diabetes in adults: one end of the rainbow. Journal of Clinical Endocrinology and Metabolism 200691 1654-1659. (doi:10.1210/jc.2005-1623)

43 Appel SJ, Wadas TM, Rosenthal RS \& Ovalle F. Latent autoimmune diabetes of adulthood (LADA): an often misdiagnosed type of diabetes mellitus. Journal of the American Academy of Nurse Practitioners 200921 156-159. (doi:10.1111/j.1745-7599. 2009.00399.x) 
44 Naik RG, Brooks-Worrell BM \& Palmer JP. Latent autoimmune diabetes in adults. Journal of Clinical Endocrinology and Metabolism 200994 4635-4644. (doi:10.1210/jc.2009-1120)

45 Isomaa B, Almgren P, Henricsson M, Taskinen MR, Tuomi T, Groop L \& Sarelin L. Chronic complications in patients with slowly progressing autoimmune type 1 diabetes (LADA). Diabetes Care 199922 1347-1353. (doi:10.2337/diacare.22.8.1347)

46 Thunander M, Thorgeirsson H, Torn C, Petersson C \& LandinOlsson M. Beta-cell function and metabolic control in latent autoimmune diabetes in adults with early insulin versus conventional treatment: a 3-year follow-up. European Journal of Endocrinology 2011164 239-245. (doi:10.1530/EJE-10-0901)

Received 9 September 2011

Revised version received 8 February 2012

Accepted 21 March 2012 